\title{
Assessing conservation status of resident and migrant birds on Hispaniola with mist-netting
}

John D Lloyd, Christopher C Rimmer, Kent P McFarland

We analyzed temporal trends in mist-net capture rates of resident $(n=8)$ and overwintering Nearctic-Neotropical migrant $(n=3)$ bird species at two sites in montane broadleaf forest of the Sierra de Bahoruco, Dominican Republic, with the goal of providing quantitative information on population trends that could inform conservation assessments. We conducted sampling at least once annually during the winter months of January March from 1997 - 2010. We found evidence of steep declines in capture rates for three resident species, including one species endemic to Hispaniola. Capture rate of Rufousthroated Solitaire (Myadestes genibarbis) declined by 3.9\% per year (95\% CL $=0 \%, 7.3 \%$ ), Green-tailed Ground-Tanager (Microligea palustris) by $6.8 \%$ (95\% CL = 3.9\%, 8.8\%), and Greater Antillean Bullfinch (Loxigilla violacea) by $4.9 \%$ (95\% CL $=0.9 \%, 9.2 \%$ ). Two rare and threatened endemics, Hispaniolan Highland-Tanager (Xenoligea montana) and Western Chat-Tanager (Calyptophilus tertius), showed statistically significant declines, but we have low confidence in these findings because trends were driven by exceptionally high capture rates in 1997 and varied between sites. Analyses that excluded data from 1997 revealed no trend in capture rate over the course of the study. We found no evidence of temporal trends in capture rates for any other residents or Nearctic-Neotropical migrants. We do not know the causes of the observed declines, nor can we conclude that these declines are not a purely local phenomenon. However, our findings, along with other recent reports of declines in these same species, suggest that a closer examination of their conservation status is warranted. Given the difficulty in obtaining spatially extensive, longterm estimates of population change for Hispaniolan birds, we suggest focusing on other metrics of vulnerability that are more easily quantified yet remain poorly described, such as extent of occurrence. 
1 2 3

$8{ }^{*}$ Corresponding author. PO Box 420, Norwich, Vermont, USA. jlloyd@vtecostudies.org

\section{Assessing conservation status of resident and migrant birds on Hispaniola with mist- netting}

\author{
John D. Lloyd ${ }^{1, *}$, Christopher C. Rimmer ${ }^{1}$, and K. P. McFarland ${ }^{1}$
}

${ }^{1}$ Vermont Center for Ecostudies, Norwich, Vermont 05055 USA

9 


\section{Abstract}

11 We analyzed temporal trends in mist-net capture rates of resident $(n=8)$ and overwintering

12 Nearctic-Neotropical migrant $(n=3)$ bird species at two sites in montane broadleaf forest of the

13 Sierra de Bahoruco, Dominican Republic, with the goal of providing quantitative information on

14 population trends that could inform conservation assessments. We conducted sampling at least

15 once annually during the winter months of January - March from $1997-2010$. We found

16 evidence of declines in capture rates for three resident species, including one species endemic to

17 Hispaniola. Capture rate of Rufous-throated Solitaire (Myadestes genibarbis) declined by 3.9\%

18 per year $(95 \% \mathrm{CL}=0 \%, 7.3 \%)$, Green-tailed Ground-Tanager (Microligea palustris) by $6.8 \%$

$19(95 \% \mathrm{CL}=3.9 \%, 8.8 \%)$, and Greater Antillean Bullfinch (Loxigilla violacea) by $4.9 \%(95 \% \mathrm{CL}$

$20=0.9 \%, 9.2 \%$ ). Two rare and threatened endemics, Hispaniolan Highland-Tanager (Xenoligea

21 montana) and Western Chat-Tanager (Calyptophilus tertius), showed statistically significant

22 declines, but we have low confidence in these findings because trends were driven by

23 exceptionally high capture rates in 1997 and varied between sites. Analyses that excluded data

24 from 1997 revealed no trend in capture rate over the course of the study. We found no evidence

25 of temporal trends in capture rates for any other residents or Nearctic-Neotropical migrants. We

26 do not know the causes of the observed declines, nor can we conclude that these declines are not

27 a purely local phenomenon. However, our findings, along with other recent reports of declines in

28 these same species, suggest that a closer examination of their conservation status is warranted.

29 Given the difficulty in obtaining spatially extensive, long-term estimates of population change

30 for Hispaniolan birds, we suggest focusing on other metrics of vulnerability that are more easily

31 quantified yet remain poorly described, such as extent of occurrence. 


\section{INTRODUCTION}

35 Hispaniola supports a notably diverse avifauna, including at least 31 endemic species (Latta et

36 al., 2006), several of which appear to be the only extant members of ancient, family-level clades

37 (Barker et al., 2013; Barker et al., 2015). Many of these taxa are of substantial conservation

38 concern given extensive habitat loss caused by ongoing deforestation in both Haiti and the

39 Dominican Republic (Stattersfield et al., 1998; Latta, 2005). None of the endemic birds of

40 Hispaniola have been well studied, however, and assessments of their conservation status are

41 often qualitative, subjective, and based largely on expert opinion (Latta and Fernandez, 2002).

42 Decisions about investments in conservation are often guided by population status (Possingham

43 et al., 2002; Rodrigues et al., 2006), and thus well-informed status assessments are critically

44 important for the effective allocation of limited funding for conservation.

45 Here, we seek to improve current understanding of the conservation status of the unique

46 and threatened assemblage of birds in montane cloud forest in Sierra de Bahoruco, Dominican

47 Republic. These forests are a hotspot of endemism on the island (Latta, 2005), support several

48 globally threatened resident bird species, and constitute a principal wintering area for the globally Vulnerable (BirdLife International, 2012) Bicknell's Thrush (Catharus bicknelli), a

50 Nearctic-Neotropical migrant. Montane cloud forests also face substantial and ongoing threats

51 from deforestation for agricultural production and expansion of human settlements, even in

52 ostensibly protected areas such as Sierra de Bahoruco National Park (BirdLife International,

53 2015). We used data collecting during 13 years of mist-netting at two different sites to estimate

54 temporal trends in capture rate, which we use as an index of change in population size and as a

55 means to draw inference about conservation status. In other tropical systems, long-term mist 
56 netting has proven a useful tool for identifying population declines in bird assemblages that are

57 otherwise difficult to monitor (e.g., Faaborg et al., 2013)

\section{METHODS}

60 From 1995-2010 we operated a standardized array of 30-35 mist nets (we used 6- and 12-m nets

61 that were 2.6-m tall with 36-mm mesh) at two remote sites in Sierra de Bahoruco, southwestern

62 Dominican Republic. The sites, Pueblo Viejo (hereafter "PUVI"; $18.2090^{\circ} \mathrm{N},-71.5080^{\circ} \mathrm{W}$ ) and

63 Palo de Agua (hereafter "PALO"; $18.2047^{\circ} \mathrm{N},-71.5321^{\circ} \mathrm{W}$ ), consist of montane cloud forest at

$64 \quad 1,775-1,850 \mathrm{~m}$ elevation in Sierra de Bahoruco National Park and are separated by $2.6 \mathrm{~km}$ of

65 contiguous forest. Both sites are characterized by a dense understory composed largely of thick

66 woody tangles, complete broadleaf canopy cover with trees reaching heights between 15 and 20

$67 \mathrm{~m}$, and an abundance of lianas and epiphytes (Veloz, 2007). We trimmed vegetation to prevent

68 overgrowth of our net lanes, but otherwise the forest at both sites was undisturbed by humans.

69 We visited PUVI at least once annually between November and May, except in 1999

70 when we did not visit either site. We made two visits in 1997 (March, November), 1998 (March,

71 November), 2002 (February, May), 2003 (February, May), and 2010 (March, November). Our

72 one visit to PUVI in 1996 occurred in early December. To minimize the potentially confounding

73 effects of seasonal variation in abundance and bird behavior that may affect capture rate, this

74 analysis does not include data collected during the May, November, and December visits.

75 Resident birds have commenced breeding by May, and so availability for capture may be

76 different during this period. Transient hatch-year birds, which likely have a very different

77 probability of capture, also begin appearing in large numbers in May. Migrant birds have 
78 departed for their breeding grounds by May, but are still arriving at our sites during November

79 and, to a lesser extent, early December.

We also visited PALO at least once annually during the same period that we visited

81 PUVI, except for 1996 and 1999-2001. As with PUVI, we excluded data collected during the

82 three November visits $(1997,1998$, and 2010). We did not visit PALO in May. At both sites in

83 1995, we only banded Nearctic-Neotropical migrants, and so we excluded data from that year

84 from this analysis. The final, censored data set for this analysis thus includes captures made

85 from $1997-2010$ (with no data collected in 1999) on dates ranging from 24 January to 21

86 March. We believe that this date range reflects a period of relative stability at our sites, after

87 migrant species have arrived, settled, and established winter territories but before resident

88 species have commenced breeding. As such, we also believe that capture rates during this period

89 are comparable among years because availability for and probability of capture should be

90 relatively constant among years.

91 At each site, we established permanent net locations along three parallel foot trails 100-

$92150 \mathrm{~m}$ apart. The area bounded by the foot trails was $\sim 25$ ha at PUVI and $\sim 15$ ha at PALO. We

93 regularly used 30 net locations at PUVI and 35 at PALO. Nets were typically operated for 3

94 days at each site, beginning in late afternoon of day 1 , from dawn to dusk on days 2 and 3 , and

95 until mid-morning on day 4 . Nets were checked hourly and closed under adverse weather

96 conditions. We recorded daily opening and closing times of each net. Both sites were netted in

97 succession each year, with set-up at the second site occurring on the day that nets were removed

98 from the first site.

99 We placed U.S. Fish and Wildlife Service aluminum leg bands on all Nearctic-

100 Neotropical migrant species and custom-made, uniquely numbered leg bands (Gey Band and Tag 
101 Company) on all Hispaniolan resident species, except for Hispaniolan Emeralds (Chlorostilbon

102 swainsonii), which was too small for our bands. We aged and sexed all North American species

103 using standard criteria according to Pyle (1997) and all resident species using criteria available in

104 field guides (Latta et al., 2006) or based on our own accumulated field knowledge. However, we

105 could only reliably age and sex a handful of species, so we pooled capture rates for all ages and

106 all sexes in our analyses.

107 We analyzed trends in capture rate for 6 endemic species that we believed were

108 adequately sampled by our methods (English common names follow Latta et al. [2006],

109 scientific names follow AOU [2015]): Narrow-billed Tody (Todus angustirostris), Green-tailed

110 Ground-Tanager (Microligea palustris), Hispaniolan Highland-Tanager (Xenoligea montana),

111 Black-crowned Palm-Tanager (Phaenicophilus palmarum), Western Chat-Tanager

112 (Calyptophilus tertius), and Hispaniolan Spindalis (Spindalis dominicensis). Quantitative data on

113 population trends are lacking for all of these species, but two are suspected of being at risk of

114 extinction: Hispaniolan Highland-Tanager is recognized as Vulnerable on the IUCN Red List

115 (BirdLife International 2012) and Endangered by Latta et al. (2006), and Western Chat-Tanager

116 is considered Critically Endangered by Latta et al. (2006). BirdLife International does not

117 recognize the taxonomic separation of Eastern Chat-Tanager (C.frugivorous) and Western Chat-

118 Tanager, and instead considers the entire species group Vulnerable (BirdLife International 2012).

119 We also analyzed standardized capture rates for the two most common non-endemic

120 residents (Rufous-throated Solitaire [Myadestes genibarbis] and Greater Antillean Bullfinch

121 [Loxigilla violacea]) and the three most frequently encountered North American migrants at our

122 sites: Bicknell's Thrush, Ovenbird (Seiurus aurocapilla), and Black-throated Blue Warbler 
123 (Setophaga caerulescens). All of the resident species that we captured breed regularly at both

124 sites (Rimmer et al., 2008; CC Rimmer, unpublished data).

125 We assumed that the number of captures of each species could be approximated by the

126 Poisson distribution and used a generalized linear model to examine temporal and spatial trends

127 in capture rate among species. The response variable was the number of unique individuals (new

128 bandings and returns from previous sessions, but not repeat captures from the same session) of

129 each species captured during each unique capture session (hence two data points for PUVI in

130 1998, when we visited in both February and March). We accounted for variation in capture

131 effort by using the number of net hours per capture session (log-transformed) as an offset in the

132 model. We calculated net hours by multiplying the number of 12-m mist nets (or their

133 equivalent; e.g., a 6 -m net open was equivalent to a $0.512-\mathrm{m}$ net) in use during each session by

134 the length of time each was open. For the purposes of standardization with other constant-effort

135 mist-netting studies, we report capture rate per 1,000 net hours (i.e., expected captures for every

1361,000 hours that 12-m net was open). The predictor variables included year, site, and the

137 interaction between site and year. We considered three models for each species: year only, site +

138 year, and site*year. We chose among these competing models with a likelihood-ratio test. We

139 estimated temporal trends using the estimated coefficient for the year effect in the best model,

140 and established an a priori significance level of $\alpha=0.05$.

141 Once we identified the best model, we examined whether we could further improve

142 model fit by adding to the best model a parameter reflecting the average multivariate El Niño-

143 Southern Oscillation (ENSO) index (MEI) during June to December prior to each banding

144 session. We used lagged values from the previous June to December because they provided a

145 measure of the relative strength of the ENSO event and thus the potential influence on rainfall 
146 during the wet and dry seasons preceding our banding sessions. As they build in strength, warm

147 ENSO events are associated with anomalously dry conditions during the late wet season

148 (September - October) and most of the subsequent dry season (November - March), and with

149 anomalously wet conditions during the early wet season (April - July) of the following year as

150 the event subsides (Chen and Taylor, 2002). We downloaded bimonthly MEI values from

151 http://www.esrl.noaa.gov/psd/enso/mei/table.html for the June to December prior to each

152 banding session, and averaged these values to produce a single average value for those six

153 months, which we then added as a covariate to the best-fitting model. We determined whether

154 addition of the MEI covariate improved model fit via a likelihood-ratio test.

155 Examination of residual plots and QQ-plots did not reveal any deviations from model

156 assumptions regarding the distribution of residuals or the relationship between residuals and

157 fitted values. For each model, we calculated the autocorrelation of residuals at each possible time

158 lag, and compared it to expectations under the null hypothesis of no autocorrelation. We found

159 no evidence of autocorrelation in residuals. We also tested the null hypothesis of no

160 autocorrelation among residuals by regressing the value of each residual against its lagged ( $t-1)$

161 value; in no case could we reject the null hypothesis (all P values $>0.05$ ). We used the ratio of

162 the residual deviance to the deviance degrees of freedom as a measure of overdispersion. We

163 found little evidence of overdispersion (residual deviance $<2$ times the residual degrees of

164 freedom), so we made no adjustment to the models (although we note that quasi-Poisson and

165 negative binomial models produce results that do not differ qualitatively from the Poisson). We

166 report pseudo- $\mathrm{R}^{2}$ as an approximate measure of the explanatory power of the best model in each

167 analysis, calculated as: $1-\frac{\text { residual deviance }}{\text { null deviance }}$. 
All analyses were conducted using R (R Core Team, 2015). All data used in this analysis

169

170

171

172

173

174

175

176

177

178

179

180

181

182

183

184

185

186

187

188

189

190 are available in Lloyd et al. (2015). Permission to band North American migrants was granted by the USGS Bird Banding Lab, under a permit issued to CCR (permit no. 23541), and research activities in the Dominican Republic were approved by the Subsecretaria de Áreas Protegidas y Biodiversidad.

\section{RESULTS}

We conducted 15 banding sessions at PUVI over 13 years and 11 banding sessions over the same period at PALO (Table 1), yielding $>22,000$ net hours. We captured a total of 31 species (Table 2). The endemic Green-tailed Ground-Tanager was the most commonly encountered species; number of captures for species included in this analysis ranged from 69 - 245 individuals (Table 2).

Capture rates declined over the course of our study for Rufous-throated Solitaire $\left(\beta_{\text {year }}=\right.$ $0.04,95 \% \mathrm{CL}=-0.076,-0.001 ; \mathrm{P}=0.04 ;$ Fig. 1$)$, Green-tailed Ground-Tanager $\left(\beta_{\text {year }}=-0.07\right.$; 95\% CL $=-0.092,-0.040 ; \mathrm{P}<0.001 ;$ Fig. 2$)$, and Greater Antillean Bullfinch $\left(\beta_{\text {year }}=-0.05 ; 95 \%\right.$ $\mathrm{CL}=-0.097,-0.009, \mathrm{P}=0.02$; Fig. 3). These estimated coefficients equate to expected annual declines in the number of captures of $3.9 \%(95 \% \mathrm{CL}=0 \%, 7.3 \%)$ for Rufous-throated Solitaire, $6.8 \%(95 \% \mathrm{CL}=3.9 \%, 8.8 \%)$ for Green-tailed Ground-Tanager, and $4.9 \%(95 \% \mathrm{CL}=0.9 \%$, 9.2\%) for Greater Antillean Bullfinch. Capture rate also varied by site for these species; for Rufous-throated Solitaire, expected counts were higher at PALO (Fig. 1), whereas for Greentailed Ground-Tanager and Greater Antillean Bullfinch counts were greater at PUVI (Figs. 2, 3).

We found no evidence of a site-by-year interaction in capture rates for any of these species. The absolute magnitude of declines in expected capture rate over the course of the study were 
191 relatively small for Rufous-throated Solitaire and Greater Antillean Bullfinch. For Rufous-

192 throated Solitaire, the decline in expected capture rate amounted to 4.5 fewer individuals

193 captured per 1,000 net hours at PALO in 2010 as compared to 1997, and 2.7 fewer individuals

194 per 1,000 net hours at PUVI over the same period of time. For Greater Antillean Bullfinch, the

195 declines were even smaller: 1.6 fewer individuals per 1000 net hours at PALO, and 4.8 fewer

196 individuals per 1000 net hours at PUVI. The magnitude of the decline in expected capture rate

197 for Green-tailed Ground-Tanager was more substantial: expected capture rate in 2010 was 5.7

198 fewer individuals per 1,000 net hours than in 1997 at PALO, and 17.0 fewer individuals per

1991,000 net hours at PUVI.

200 We did not find that adding the MEI as a covariate improved model fit. The reduction in 201 residual deviance gained by adding MEI as a covariate to the best model was consistently small $202(0.01-1.0)$ and always non-significant (all likelihood-ratio test P-values $>0.28$ ). The pseudo- $\mathrm{R}^{2}$ 203 of the best model for Green-tailed Ground-Tanager was relatively high (76\%), whereas the 204 percent of variation explained by the best model was moderate for Greater Antillean Bullfinch 205 (47\%) and low for Rufous-throated Solitaire (30\%).

206 Two other endemics, Hispaniolan Highland-Tanager and Western Chat-Tanager, showed

207 mixed evidence of declines in capture rate. The preferred model for Hispaniolan Highland-

208 Tanager included significant effects of year $\left(\beta_{\text {year }}=-0.23 ; 95 \% \mathrm{CL}=-0.35,-0.12 ; \mathrm{P}<0.001\right)$, site $209\left(\beta_{\text {site }}=-418.8 ; 95 \% \mathrm{CL}=-687.1,168.3 ; \mathrm{P}=0.001\right)$, and their interaction $\left(\beta_{\text {site*year }}=0.21 ; 95 \%\right.$

$210 \mathrm{CL}=0.084,0.344 ; \mathrm{P}=0.001)($ Fig. 4). Adding MEI as a covariate did not improve model fit

211 (deviance reduction $=1.4, \mathrm{P}=0.31)$. The best model explained $38 \%$ of observed variation in

212 capture rate. Declines in expected number of captures were predicted for both sites, but the rate

213 of decline was greater at PALO than at PUVI (Fig. 2). At PALO, the expected annual decline 
214 was $20.5 \%(95 \% \mathrm{CL}=11.7 \%, 28.8 \%)$, while at PUVI it was $2.1 \%(95 \% \mathrm{CI}=0.4 \%-3.9 \%)$.

215 However, the significance of these relationships was driven by the exceptionally high capture

216 rate at PALO in 1997. When we excluded data from 1997, none of the regression coefficients,

217 including year $\left(\beta_{\text {year }}{ }^{=}-0.05 ; 95 \% \mathrm{CL}=-0.12,0.02 ; \mathrm{P}=0.12\right)$, were significantly different from 218 zero.

219 The situation for Western Chat-Tanager was more complicated, as the preferred model 220 also included significant effects for year $\left(\beta_{\text {year }}=-0.10 ; 95 \% \mathrm{CL}=-0.173,-0.026 ; \mathrm{P}=0.008\right)$, site $221\left(\beta_{\text {site }}=-245.1 ; 95 \% \mathrm{CL}=-440.2,-52.8 ; \mathrm{P}=0.013\right)$, and their interaction $\left(\beta_{\text {site } * \text { year }}=0.122 ; 95 \%\right.$ $222 \mathrm{CL}=0.026,0.220 ; \mathrm{P}=0.001)$, but the interaction was such that expected capture rates declined 223 at PALO while remaining steady or gaining slightly at PUVI (Fig. 5). Expected captures at 224 PALO declined by $9.5 \%(95 \% \mathrm{CL}=2.5 \%, 15.9 \%)$ each year, whereas at PUVI expected 225 captures rose by $2.3 \%$ per year $(95 \% \mathrm{CL}=0 \%, 4.8 \%)$. However, as with Hispaniolan Highland-

226 Tanager, the statistically significant results were entirely due to the especially high capture rate 227 in 1997; when we excluded that point and re-ran the analysis, none of the regression coefficients 228 differed significantly from zero. Adding MEI as a covariate did not significantly improve model 229 fit, although the effect was stronger than in other species (deviance reduction $=3.5, \mathrm{P}=0.06$;

$230 \beta_{\text {MEI }}=-0.20 ; 95 \% \mathrm{CL}=-0.426,0.009 ; \mathrm{P}=0.07$ ). The pseudo- $\mathrm{R}^{2}$ for the best model (site*year) 231 was $30 \%$.

232 We found no evidence of any temporal trend in capture rate for Narrow-billed Tody $\left(\beta_{\text {year }}\right.$ $233=0.020 ; 95 \% \mathrm{CL}=-0.017,0.058 ; \mathrm{P}=0.30)$, Black-crowned Palm-Tanager $\left(\beta_{\text {year }}=-0.028 ; 95 \%\right.$ $234 \mathrm{CL}=-0.079,0.025 ; \mathrm{P}=0.30)$, or Hispaniolan Spindalis $\left(\beta_{\text {year }}=0.009 ; 95 \% \mathrm{CL}=-0.040,0.061\right.$; $235 \mathrm{P}=0.72$ ), nor did we find evidence for temporal trends in any of the migrant species (Bicknell's 236 Thrush: $\beta_{\text {year }}=-0.003 ; 95 \% \mathrm{CL}=-0.042,0.037 ; \mathrm{P}=0.87$; Ovenbird: $\beta_{\text {year }}=0.004 ; 95 \% \mathrm{CL}=$ - 
237 0.029, 0.039; $\mathrm{P}=0.78$; Black-throated Blue Warbler: $\beta_{\text {year }}=0.013 ; 95 \% \mathrm{CL}=-0.038,0.065 ; \mathrm{P}=$

238 0.633). In no case was model fit improved by the inclusion of MEI as a covariate (range of

239 deviance reduction: $0.27-3.1$; all likelihood-ratio test P-values $>0.09$ ).

\section{DISCUSSION}

Captures rates of three resident species - including one Hispaniolan endemic - declined

243 significantly over the course of this study. Captures of Green-tailed Ground-Tanager declined by

$244 \sim 63 \%$ from 1997-2010, Rufous-throated Solitaire by $\sim 43 \%$, and Greater Antillean Bullfinch by

$245 \sim 51 \%$. The relationship between capture rate and time was strong for Green-tailed Ground-

246 Tanager, but was relatively weak for the other two species as evidenced by low pseudo- $\mathrm{R}^{2}$ values

247 and substantial scatter in observed capture rates. In addition, the absolute magnitude of the

248 declines was small for Rufous-throated Solitaire and Greater Antillean Bullfinch, amounting to

249 roughly $1-5$ fewer birds caught per 1,000 net hours in 2010 as compared to 1997 . The

250 magnitude of the decline in Green-tailed Ground-Tanager was greater, with expected capture

251 rates in 2010 ranging from roughly 6 fewer individuals captured per 1,000 net hours at PALO to

25217 fewer individuals captured per 1,000 net hours at PUVI. As such, we have relatively more

253 confidence in the biological significance of the modeled decline in capture rate of Green-tailed

254 Ground-Tanager. All of these species are currently considered Least Concern by the IUCN

255 (BirdLife International, 2012). However, if the trends that we observed are characteristic of

256 changes occurring range-wide, and if capture rate provides a valid index of population size, then

257 all of these species would meet the criteria for uplisting to Vulnerable ( $\geq 30 \%$ decline over 10

258 years; IUCN, 2012). 
We have low confidence in estimated trends for two other Hispaniolan endemics,

260 Hispaniolan Highland-Tanager and Western Chat-Tanager. Trends in capture rate varied

261 between sites and were influenced by large numbers of individuals captured in 1997, the first

262 year considered in this analysis. We do not understand why capture rates were so high in 1997,

263 but we are hesitant to conclude that these species declined solely on the basis of results obtained

264 in that year. An equally plausible conclusion is that populations of these two species at our study

265 sites were not in long-term decline, and that data from 1997 reflected an unusual and temporary,

266 if unexplained, increase in the local population available for capture in our nets. Unfortunately,

267 we did not collect information on resident species during our initial visit in 1995, and the only

268 data from 1996 were collected at one site (PUVI) at a different time of year (early December)

269 and so provide little insight into the apparently high capture rates observed in 1997.

270 Capture rates of the remaining endemics (Narrow-billed Tody, Black-crowned Palm-

271 Tanager, and Hispaniolan Spindalis) were stable during the course of our study. The three

272 migrant species that we examined also showed no trend in capture rate, largely in keeping with

273 concurrent trends estimated on their breeding grounds. Ovenbird and Black-throated Blue

274 Warbler surveys on the breeding grounds indicated a stable to modestly increasing population

275 over the period of our study (Sauer et al., 2014); range-wide estimates of population trend are not

276 available for Bicknell's Thrush, although local declines have been noted (Lambert et al., 2008).

277 We can only speculate about the causes of observed declines. We saw no clear

278 suggestion that declines were related to climate or weather. Reduced food availability mediated

279 by reduced precipitation during warm-phase ENSO events can limit survival of migrant and

280 resident birds in the Neotropics (Sillett, Holmes \& Sherry, 2000; Wolfe et al., 2015), but we

281 found no evidence of a relationship between MEI and capture rate for any species. The intact 
282 montane forest that characterized our study sites may be resistant to ENSO-driven variability in

283 precipitation (e.g., Wolfe et al., 2015), but the lack of any clear signal of ENSO may also reflect

284 variability in the effect of ENSO on local and regional precipitation patterns (e.g., Jury,

285 Malmgren \& Winter, 2007). Hurricanes can have profound effects on bird populations in the

286 Caribbean (Waide 1991; Wiley and Wunderle 1993), but we saw no obvious relationship

287 between the passage of tropical cyclones through our study sites and changes in capture rate. For

288 example, Hurricane Georges, the most powerful cyclone to affect our study area during the

289 course of this research, caused widespread damage across the Dominican Republic and passed

290 almost directly over Sierra de Bahoruco in September 1998. We did not visit either study site in

291 1999, but capture rates for most species were relatively high in 2000, even among those species

292 that showed long-term declines in capture rate. If hurricane-related changes in habitat conditions

293 were responsible for the declines that we observed, then we would have expected a sharp drop in

294 capture rate after 1998. We also suspect little role for local changes in vegetation structure or

295 composition. Anthropogenic effects on vegetation structure at the sites were minimal and

296 restricted to our maintenance of net lanes. Surrounding forests were also largely free from

297 direct, human-caused disturbance. Natural disturbances were limited to a few small, tree-fall

298 canopy gaps, and we consider it unlikely that patchy successional changes contributed

299 substantially to any long-term declines in capture rate.

$300 \quad$ Both study sites support large populations of introduced rats (Rattus rattus and $R$.

301 norvegicus), which are probably important predators of adult birds and nests (Townsend et al.,

302 2009), but why they would affect only certain species is unclear. Also unclear is why rats, which

303 have been established on most islands of the Caribbean for several hundred years (Harper and

304 Bunbury, 2015), including presumably Hispaniola, would precipitate recent declines. Finally, 
305 habitat loss outside of the study area caused by extensive, ongoing deforestation (BirdLife

306 International, 2015) could drive local declines by reducing the regional population and thus

307 reducing both recruitment into local populations and the number of transient individuals exposed

308 to our sampling efforts.

309 Capture rate in mist nets is often a valid index of abundance, and trends in capture rate

310 are usually - but not always - correlated with population trends estimated using other methods

311 (Dunn and Ralph, 2002). However, changes in capture rate might also reflect changes in our

312 ability to capture individuals, rather than changes in the number of individuals available for

313 capture. Although capture probability need not be constant, the validity of our inferences

314 regarding changes in abundance over time requires that variation in capture probability was less

315 than variation in abundance (Johnson, 1998). We controlled for variation in effort and held

316 constant other factors that might influence capture rate independently of abundance, such as net

317 location, mesh size, vegetation structure immediately around the nets, and seasonal timing of

318 capture efforts. As with any study that uses capture rates as an index of abundance, we cannot

319 rule out the possibility that individual birds learned to avoid our net locations, which could lead

320 to changes in capture rate independent of changes in abundance. However, we believe that net

321 avoidance is an unlikely explanation for the observed declines, given that we opened nets only

322 for several days per year.

323 Assuming that trends in capture rate reflected trends in the number of individuals

324 available for capture, how might these findings inform assessments of conservation status?

325 Whether the trends described here were purely a local phenomenon is uncertain. We sampled a

326 small number $(\mathrm{n}=2)$ of purposefully selected sites (undisturbed by human activity) within the

327 montane cloud forest of Sierra de Bahoruco, and so we cannot use these data to draw inference 
328 more broadly about the range-wide status of any species. Nonetheless, when combined with

329 other sources of information on population trends, our findings are useful in highlighting which

330 species warrant closer scrutiny. For example, Green-tailed Ground-Tanager, Rufous-throated

331 Solitaire, and Greater Antillean Bullfinch have been reported as declining in other recent

332 evaluations of conservation status (Latta et al., 2006; BirdLife International, 2012), which

333 suggests, but does not demonstrate, that the patterns we described may not be limited solely to

334 our study areas.

335 Even with these findings, which represent the only long-term, quantitative information

336 available on population trends for these species, substantial uncertainty remains regarding range-

337 wide patterns of vulnerability. Intensive studies like ours can provide useful information about

338 ecology and local demographics, but are limited in the scope of inference that they allow

339 regarding overall changes in population parameters. Given the challenges of funding and

340 executing geographically extensive biodiversity monitoring studies, especially in the tropics, it is

341 unlikely that any additional quantitative information can be collected in the short-term that

342 would help resolve this uncertainty. As such, a useful next step might be to focus on other

343 criteria important in assessing vulnerability (IUCN 2012), such as extent of occurrence, that

344 could be quantified using currently available data (e.g., species distribution modeling using data

345 from sources like eBird) but which are not well described at present.

\section{Acknowledgments}

348 Field assistance was provided by many local and international partners, but several deserve

349 special mention: J. Almonte, E. Garrido, J. Goetz, J. Klavins, R. Ortiz, and J. Townsend. 


\section{References}

355

356

357

358

359

360

361

362

363

364

365

366

367

368

369

370

371

372

373

374

375

376

377

378

379

380

381

382

American Ornithologists' Union [AOU]. 2015. Checklist of North and Middle American Birds. Available at http://checklist.aou.org/taxa/ (accessed 16 October 2015).

Barker, FK., Burns KJ, Klicka J, Lanyon SM, Lovette I. 2015. New insights into New World biogeography: an integrated view from the phylogeny of blackbirds, cardinals, sparrows, tanagers, warblers, and allies. The Auk: Ornithological Advances 132:333-348. DOI: 10.1642/AUK-14-110.1.

Barker, FK., Burns KJ, Klicka J, Lanyon SM, Lovette I. 2013. Going to extremes: Contrasting rates of diversification in a recent radiation of new world passerine birds. Systematic Biology 62:298-320. DOI: 10.1093/sysbio/sys094.

BirdLife International. 2012. The IUCN Red List of Threatened Species. Version 2015.2. Available at http://www.iucnredlist.org (accessed 20 July 2015)

BirdLife International. 2015. Important Bird Areas factsheet: Sierra de Bahoruco. Available at http://www.birdlife.org/datazone/sitefactsheet.php?id=19839 (Accessed 20 July 2015)

Chen AA, Taylor MA. 2002. Investigating the link between early season Caribbean rainfall and the E1 Niño+1 year. International Journal of Climatology 22:87-106. DOI:10.1002/joc. 711 .

Dunn, EH, Ralph CJ. 2002. Use of mist nets as a tool for bird population monitoring. Studies in Avian Biology 29:1-6.

Faaborg J, Arendt WJ, Toms JD, Dugger KM, Cox WA, Mora MC. 2013. Long-term decline of a winter-resident bird community in Puerto Rico. Biodiversity Conservation 22:63-75. DOI:10.1007/s10531-012-0399-7.

Harper, GA, Bunbury N. 2015. Invasive rats on tropical islands: their population biology and impacts on native species. Global Ecology and Conservation 3:607-627.

DOI:10.1016/j.gecco.2015.02.010.

IUCN. 2012. IUCN Red List Categories and Criteria: Version 3.1. Second edition. Gland and Cambridge: IUCN.

Johnson DH. 2008. In defense of indices: the case of bird surveys. Journal of Wildlife Management 72:857-868. DOI:10.2193/2007-294. 
383

Jury M, Malmgren BA, Winter A. 2007. Subregional precipitation climates of the Caribbean and relationships with ENSO and NAO. Journal of Geophysical Research 112:D16107. DOI:10.1029/2006JD007541.

Lambert JD, King DI, Buonaccorsi JP, Prout LS. 2008. Decline of a New Hampshire Bicknell's Thrush population, 1993-2003. Northeastern Naturalist 15:607-618. DOI: 10.1656/10926194-15.4.607.

Latta SC. 2005. Complementary areas for conserving avian diversity on Hispaniola. Animal Conservation 8:69-81. DOI: 10.1017/S136794300400188X.

Latta S, Fernandez E. 2002. Avian conservation planning in the Caribbean: experience and recommendations from the Dominican Republic. In: Ralph C and Rich T, editors. Bird Conservation Implementation and Integration in the Americas: Proceedings of the Third International Partners in Flight Conference. Albany, CA: Pacific Southwest Research Station, Forest Service, U.S. Department of Agriculture, 254-257.

Latta S, Rimmer C, Keith A, Wiley J, Raffaele H, McFarland K, Fernandez E. 2006. Birds of the Dominican Republic and Haiti. Princeton: Princeton University Press.

Lloyd J, McFarland K, Rimmer C, Vermont Center for Ecostudies. 2015. Sierra de Bahoruco constant-effort mist netting. KNB Data Repository. DOI:10.5063/F1M906K7.

Possingham HP, Andelman SJ, Burgman MA, Medellín RA, Master LL, Keith DA. 2002. Limits to the use of threatened species lists. Trends in Ecology and Evolution 17:503-507. DOI: 10.1016/S0169-5347(02)02614-9.

Pyle, P. 1997. Identification Guide to North American Birds. Part I. Bolinas, CA: Slate Creek Press.

R Core Team. 2015. R: A language and environment for statistical computing. Vienna: R Foundation for Statistical Computing. Available at: http://www.R-project.org

Rimmer CC, Woolaver LG, Nichols RK, Fernández EM, Latta SC, Garrido E. 2008. First description of nests and eggs of two Hispaniolan endemic species: Western Chat-tanager (Calyptophilus tertius) and Hispaniolan Highland-tanager (Xenoligea montana). The Wilson Journal of Ornithology 120:190-195. DOI: 10.1676/06-184.1.

Rodrigues AS, Pilgrim JD, Lamoreux JF, Hoffmann M, Brooks TM. 2006. The value of the IUCN Red List for conservation. Trends in Ecology and Evolution 21:71-76. DOI: 10.1016/j.tree.2005.10.010.

Sauer JR, Hines JE, Fallon JE, Pardieck KL, Ziolkowski, Jr DJ, Link WA. 2014. The North American Breeding Bird Survey, Results and Analysis 1966 - 2013. Version 01.30.2015. Available at http://www.mbr-pwrc.usgs.gov/bbs/ (Accessed 20 July 2015) 
417 Sillett TS, Holmes RT, Sherry TW. 2000. Impacts of a global climate cycle on population dynamics of a migratory songbird. Science 288:2040-2042. DOI: 10.1126/science.288.5473.2040.

Stattersfield A, Crosby M, Long A, Wege D. 1998. Endemic Bird Areas of the World: Priorities 421 for Biodiversity Conservation. Cambridge: BirdLife International.

Townsend JM, Rimmer CC, Brocca J, McFarland KP, Townsend AK. 2009. Predation of a wintering migratory songbird by introduced rats: can nocturnal roosting behavior serve as predator avoidance? The Condor 111:565-569. DOI: 10.1525/cond.2009.090062.

425

426

427

428 429

Townsend JM, Rimmer CC, McFarland KP. 2010. Winter territoriality and spatial behavior of Bicknell's Thrush (Catharus bicknelli) at two ecologically distinct sites in the Dominican Republic. The Auk 127:514-522.

Veloz A. 2007. Flora and vegetation of Monte Jota, Dominican Republic. Moscosoa 16:206217.

Waide RB. 1991. The effect of Hurricane Hugo on bird populations in the Luquillo Experimental Forest, Puerto Rico. Biotropica 23:475-480. DOI: 10.2307/2388269

Wiley JW, Wunderle Jr JM. 1993. The effects of hurricanes on birds, with special reference to Caribbean islands. Bird Conservation International 3:319-349. DOI: $10.1017 / \mathrm{S} 0959270900002598$.

Wolfe JD, Ralph CJ, Elizondo, P. 2015. Changes in the apparent survival of a tropical bird in response to the El Niño Southern Oscillation in mature and young forest in Costa Rica. Oecologia 178:715-721. DOI: 10.1007/s00442-015-3256-z. 
1

Trends in capture rate of Rufous-throated Solitaire (Myadestes genibarbis)

Observed capture rate (dots) of Rufous-throated Solitaire and changes in expected capture rate (solid line; shaded area $=95 \%$ confidence interval) per 1000 net-hours at two sites $($ PALO $=$ Palo de Agua, PUVI = Pueblo Viejo $)$ in montane broadleaf forest of Sierra de Bahoruco, Dominican Republic.

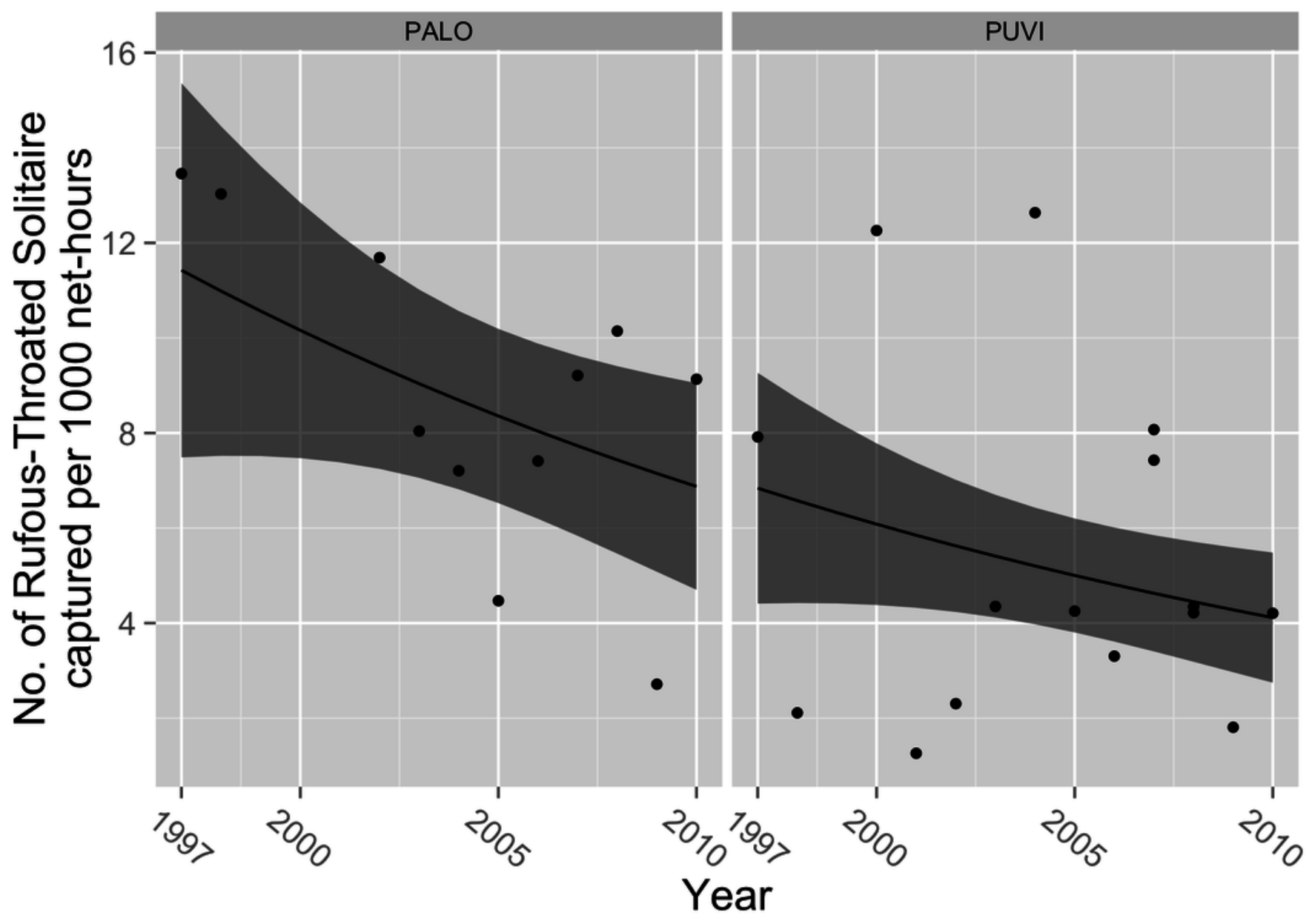


2

Trends in capture rate of Green-tailed Ground-Tanager (Microlegia palustris)

Observed capture rate (dots) of Green-tailed Ground-Tanager and changes in expected capture rate (solid line; shaded area $=95 \%$ confidence interval) per 1000 net-hours at two sites $($ PALO $=$ Palo de Agua, PUVI = Pueblo Viejo $)$ in montane broadleaf forest of Sierra de Bahoruco, Dominican Republic.

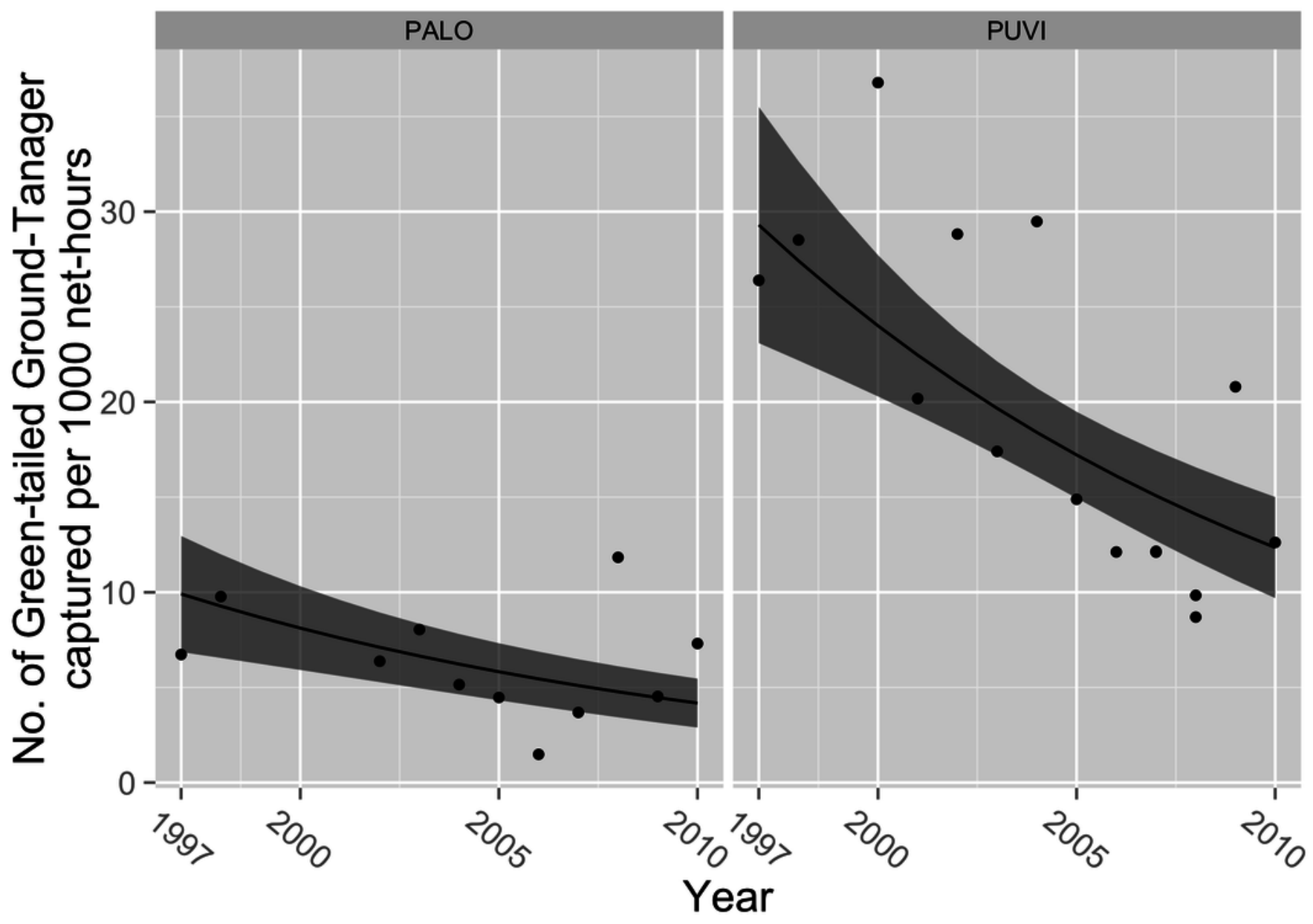




\section{3}

Trends in capture rate of Greater Antillean Bullfinch (Loxigilla violacea)

Observed capture rate (dots) of Greater Antillean Bullfinch and changes in expected capture rate (solid line; shaded area $=95 \%$ confidence interval) per 1000 net-hours at two sites (PALO = Palo de Agua, PUVI = Pueblo Viejo $)$ in montane broadleaf forest of Sierra de Bahoruco, Dominican Republic.

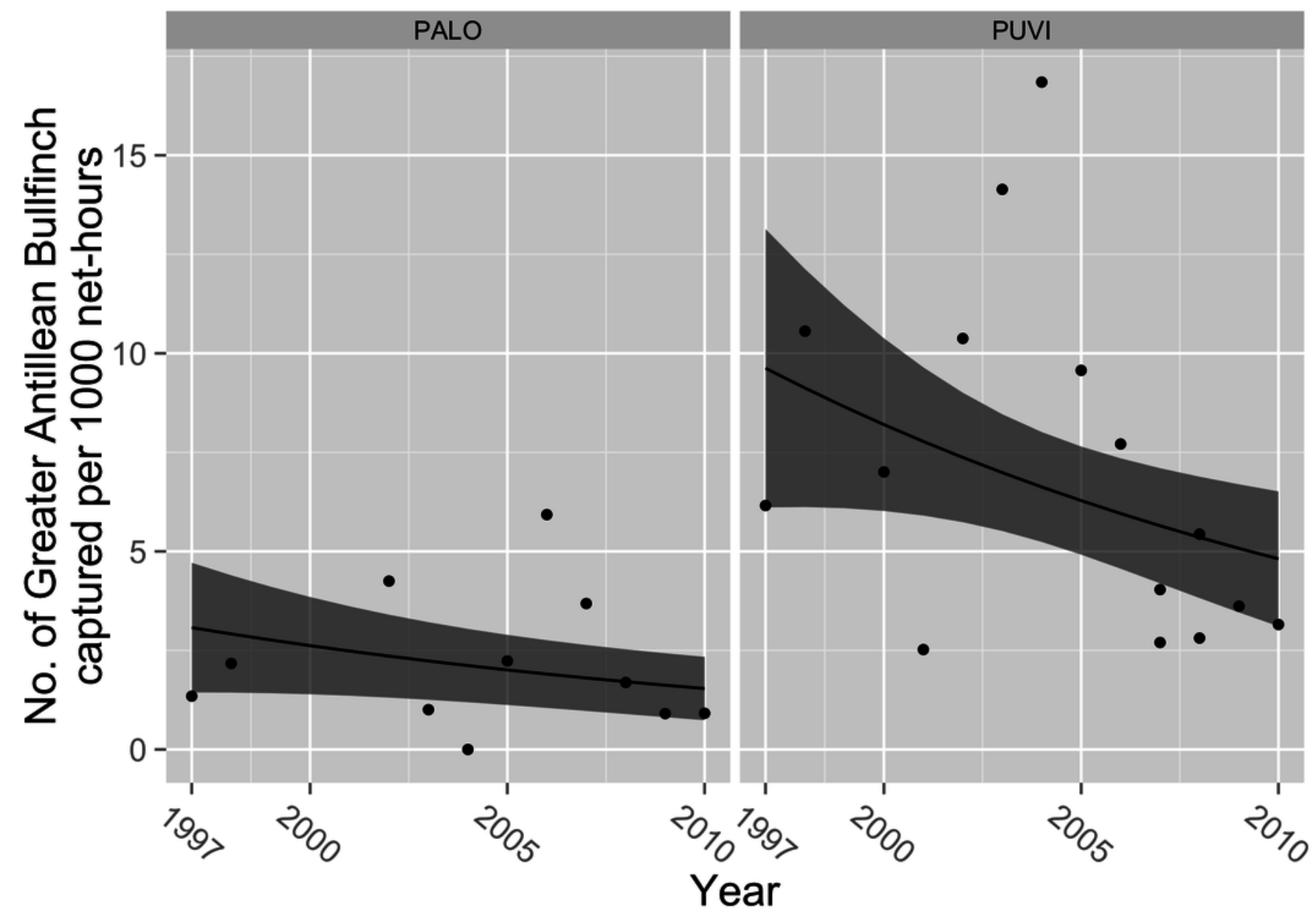


4

Trends in capture rate of Hispaniolan Highland-Tanager (Xenolegia montana)

Observed capture rate (dots) of Hispaniolan Highland-Tanager and changes in expected capture rate (solid line; shaded area $=95 \%$ confidence interval) per 1000 net-hours at two sites $($ PALO $=$ Palo de Agua, PUVI = Pueblo Viejo) in montane broadleaf forest of Sierra de Bahoruco, Dominican Republic.

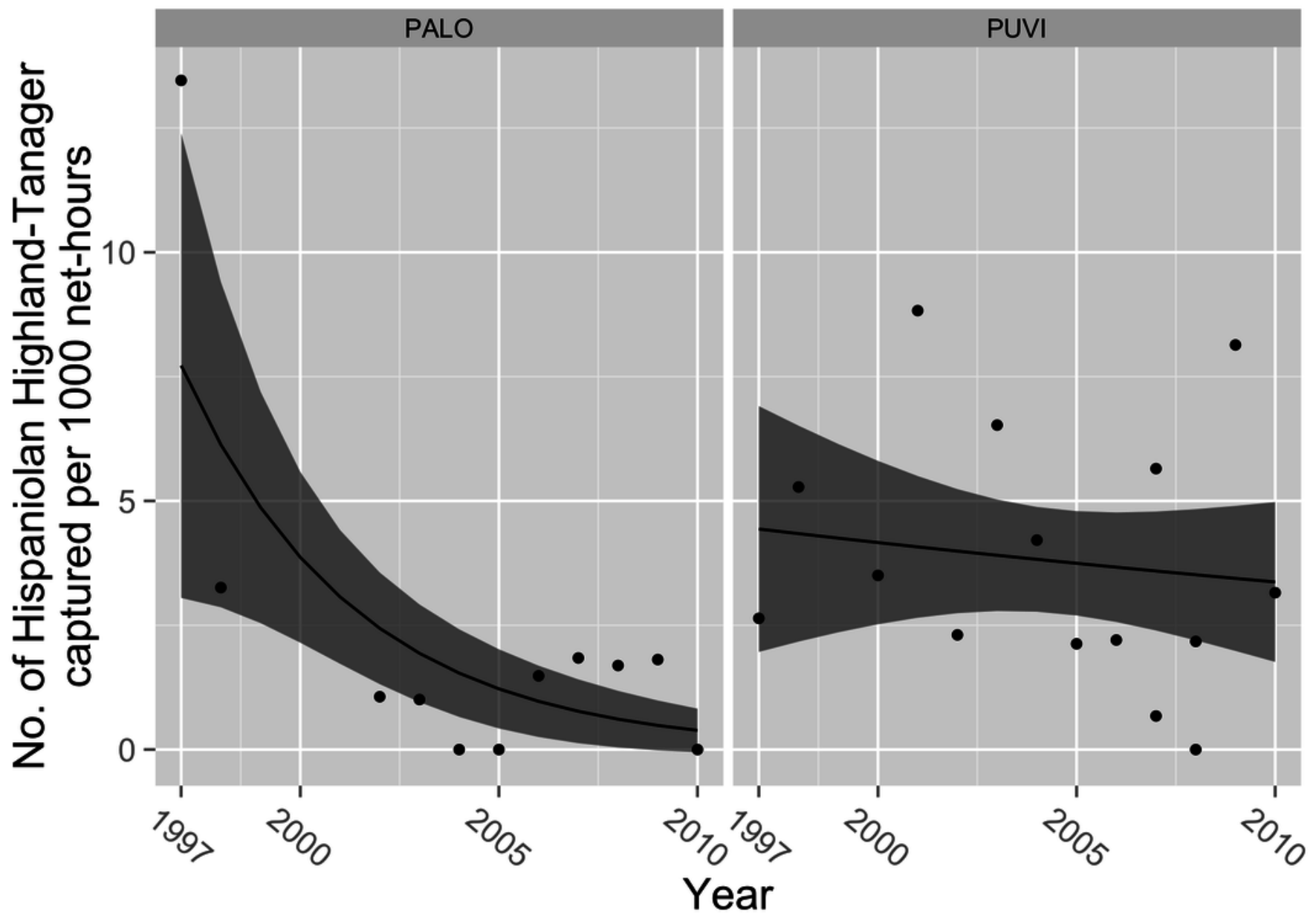


5

Trends in capture rate of Western Chat-Tanager (Calyptophilus tertius)

Observed capture rate (dots) of Western Chat-Tanager and changes in expected capture rate (solid line; shaded area $=95 \%$ confidence interval) per 1000 net-hours at two sites (PALO = Palo de Agua, PUVI = Pueblo Viejo) in montane broadleaf forest of Sierra de Bahoruco, Dominican Republic.

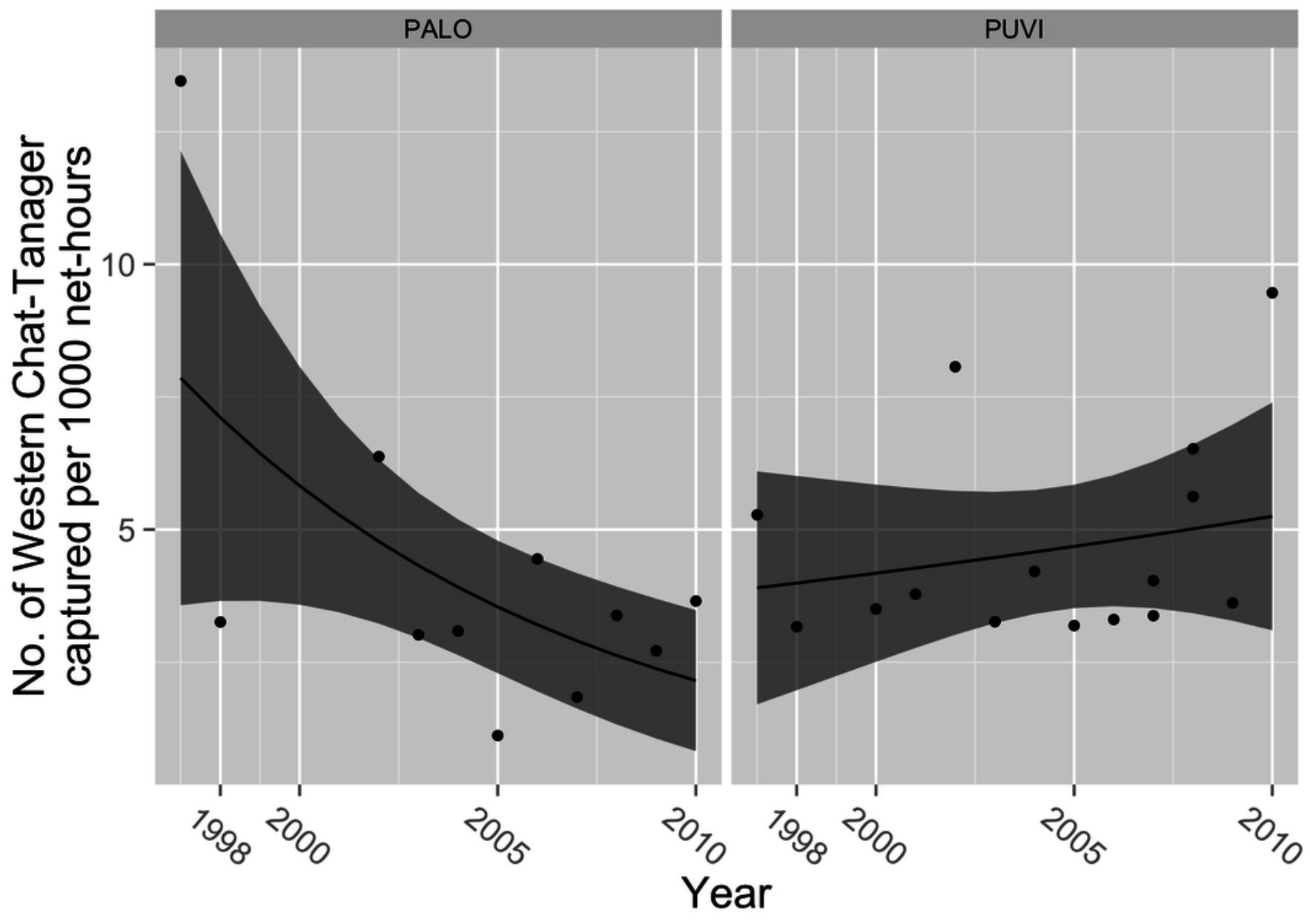




\section{Table 1 (on next page)}

Summary of capture effort.

Dates of banding sessions and total net hours at two sites in the Sierra de Bahoruco, Dominican Republic from 1997-2010. 


\begin{tabular}{|c|c|c|}
\hline Date & Site $^{a}$ & Net hours ${ }^{b}$ \\
\hline \multirow[t]{2}{*}{1997 February 28 - March 08} & PUVI & 1136.8 \\
\hline & PALO & 743.1 \\
\hline \multirow[t]{2}{*}{1998 March 04 - March 11} & PUVI & 947.0 \\
\hline & PALO & 921.0 \\
\hline \multirow[t]{2}{*}{2000 January 24 - January 27} & PUVI & 571.0 \\
\hline & PALO & 0 \\
\hline \multirow[t]{2}{*}{2001 January 30 - February 05} & PUVI & 793.0 \\
\hline & PALO & 0 \\
\hline \multirow[t]{2}{*}{2002 February 10 - February 17} & PUVI & 867.5 \\
\hline & PALO & 941.0 \\
\hline \multirow[t]{2}{*}{2003 January 30 - February 11} & PUVI & 919.5 \\
\hline & PALO & 995.0 \\
\hline \multirow[t]{2}{*}{2004 February 19 - February 28} & PUVI & 474.9 \\
\hline & PALO & 971.5 \\
\hline \multirow[t]{2}{*}{2005 February 04 - February 10} & PUVI & 940.5 \\
\hline & PALO & 895.8 \\
\hline \multirow[t]{2}{*}{2006 January 26 - January 31} & PUVI & 907.9 \\
\hline & PALO & 674.8 \\
\hline \multirow[t]{2}{*}{2007 January 31 - February 07} & PUVI & 1481.0 \\
\hline & PALO & 1085.8 \\
\hline \multirow[t]{2}{*}{2007 March 13 - March 17} & PUVI & 1239 \\
\hline & PALO & 0 \\
\hline \multirow[t]{2}{*}{2008 February 07 - February 12} & PUVI & 920.0 \\
\hline & PALO & 591.5 \\
\hline \multirow[t]{2}{*}{2008 March 13 - March 16} & PUVI & 711.5 \\
\hline & PALO & 0 \\
\hline \multirow[t]{2}{*}{2009 February 13 - February 20} & PUVI & 1106.0 \\
\hline & PALO & 1105.0 \\
\hline \multirow[t]{2}{*}{2010 March 14 - March 21} & PUVI & 951.0 \\
\hline & PALO & 1095.0 \\
\hline
\end{tabular}

1 a PUVI = Pueblo Viejo, PALO = Palo de Aqua

$2{ }^{\mathrm{b}}$ Net hours $=$ total number of $12-\mathrm{m}$-equivalent nets $*$ number of hours open 3 


\section{Table 2 (on next page)}

Summary of number of individuals captured.

Number of individuals captured during annual banding sessions conducted at two sites in the Sierra de Bahoruco, Dominican Republic from 1997-2010. 


\begin{tabular}{|c|c|}
\hline Species & $\begin{array}{c}\text { Total individuals } \\
\text { captured }\end{array}$ \\
\hline Sharp-shinned Hawk (Accipiter striatus) & 12 \\
\hline White-fronted Quail-Dove (Geotrygon leucometopia)* & 7 \\
\hline Hispaniolan Parakeet (Psittacara chloropterus)* & 1 \\
\hline Hispaniolan Emerald (Chlorostilbon swainsonii)*,1 & 47 \\
\hline Narrow-billed Tody (Todus angustirostris)* & 140 \\
\hline Hispaniolan Woodpecker (Melanerpes striatus)* & 22 \\
\hline Hispaniolan Trogon (Priotelus roseigaster)* & 10 \\
\hline Hispaniolan Pewee (Contopus hispaniolensis)* & 43 \\
\hline Greater Antillean Elaenia (Elaenia fallax) & 29 \\
\hline Rufous-throated Solitaire (Myadestes genibarbis) & 126 \\
\hline Bicknell's Thrush (Catharus bicknelli) & 149 \\
\hline La Selle Thrush (Turdus swalesi)* & 22 \\
\hline Red-legged Thrush (Turdus plumbeus) & 31 \\
\hline Gray Catbird (Dumetella carolinensis) & 1 \\
\hline Ovenbird (Seiurus aurocapilla) & 162 \\
\hline Worm-eating Warbler (Helmitheros vermivorum) & 4 \\
\hline Black-and-white Warbler (Mniotilta varia) & 28 \\
\hline Swainson's Warbler (Limnothlypis swainsonii) & 7 \\
\hline Kentucky Warbler (Geothlypis formosa) & 1 \\
\hline Common Yellowthroat (Geothlypis trichas) & 2 \\
\hline American Redstart (Setophaga ruticilla) & 3 \\
\hline Black-throated Blue Warbler (Setophaga caerulescens) & 83 \\
\hline Pine Warbler (Setophaga pinus) & 1 \\
\hline Hispaniolan Highland-Tanager (Xenoligea montana)* & 69 \\
\hline Green-tailed Ground-Tanager (Microligea palustris)* & 245 \\
\hline Banaquit (Coereba flaveola) & 4 \\
\hline Black-crowned Palm-Tanager (Phaenicophilus palmarum)* & 77 \\
\hline Western Chat-Tanager (Calyptophilus tertius)* & 72 \\
\hline Hispaniolan Spindalis (Spindalis dominicensis)* & 85 \\
\hline Black-faced Grassquit (Tiaris bicolor) & 28 \\
\hline Greater Antillean Bullfinch (Loxigilla violacea) & 86 \\
\hline
\end{tabular}

2 *Hispaniolan endemic.

$3{ }^{1}$ The total number of unique individuals captured is unknown because we could not permanently

4 mark individuals with leg bands. 